\title{
A STUDY ON IVERMECTIN RESIDUES IN THE CATTLE MEAT IN SOME AREAS AT KAFER ELSHEKH GOVERNORATE
}

Baz. G. M.; El Dakroury M. F.; Barakat M. El. S and Elewa A. M.

\section{ABSTRACT}

The aim of the present work was to study the incidence of ivermectin residues in cattle meat in some areas at Kafer Elshekh Governorate. Also, the stability of this drug for different methods of conventional cooking (grilling, boiling and frying. Forty random cattle meat samples were collected from butcher shops in some areas at Kafer Elshekh governorate. Each sample was kept in separate sterile plastic bag and transferred to the lab in an insulated ice box for detection of their content of ivermectin residues using high performance liquid chromatography (HPLC) technique. The results indicated that $7.50 \%$ of the collected meat samples were found to contain ivermectin residue below the maximum residual limits. Also, it could be stated that conventional cooking couldn't be considered a safeguard against ingestion of residues of ivermectin where grilling, boiling and frying of the positive samples induced loses of $25.4 \%, 30.9 \%$ and $23.6 \%$ of ivermectin residues content respectively.

\section{INTRODUCTION}

Ivermectin is a group of chemically related macrocyclic lactones produced by fermentation of actinomycete Streptomyces avermitilis. It had a potent endo-and ectoparasitic agent with a broad spectrum of activity in several animal species including cattle, sheep, pigs, horses and 
humans. The recommended dose in cattle is $0.2 \mathrm{mg} / \mathrm{kg}$ orally or subcutaneously. Ivermectin acts by increasing the membrane permeability to chloride ions (Adam, 2001 and Sweetman,2009).

Ivermectin is not recommended during pregnancy (teratogenic in animals ). The residues of ivermectin are responsible for several health hazards, it may induce mild Mazzotti reaction, including fever, pruritus, arthralgia, myalgia, postural hypotension, oedema, lymphadenopathy, gastrointestinal symptoms, soar throat, cough, and headache therefore becomes essential that the residues be strictly regulated from food safety point of view (James and Reynolds, 1993 and Koesukwiwat et al., 2007).

Ivermectin residues may be found in various products of animal origin like milk and meat (Bassissi et al., 2004). Chiu et al. (1990) examined the tissue distribution of ivermectin in cattle, sheep, and rats, and found that fat and liver tissues had the highest residue concentrations, whereas muscle tissue contained the lowest concentrations. Tissue redistribution is not affected by rout of administration (Adam, 2001). After injection of ivermectin, residues in all tissues tested approached zero by day 24 (Robert and Arthur, 1990).

Meat withdrawal time in subcutaneous injection in beef cattle was 35 day (Baynes et al., 2000) while, maximum residual limit in meat is $0.010 \mu \mathrm{g} / \mathrm{g}$ in USA and Canada (Veterinary Drugs Directorate, 2011 and FDA, 2011). Moreno, et al. (2008) measured ivermectin residues in muscular tissues obtained from various anatomical locations after subcutaneous administration of ivermectin to sheep.Samples were frozen at $-20^{\circ} \mathrm{C}$ until analyzed by HPLC. The highest residual concentrations were found at 15 days post-treatment. 
After correction for sample weight changes during cooking, no major losses were observed for residues of ivermectin, oxyclozanide, clorsulon, closantel, albendazole, mebendazole or fenbendazole (Cooper et al., 2011). Ivermectin stability under normal cooking conditions is further studied by Rose et al. (1998) who fried, microwaved and boiled medicated cattle and pig tissues, and observed similar results. Also, Cerkvenik et al. (2001) found no degradation of ivermectin in milk pasteurised at $80^{\circ} \mathrm{C}$, boiled at $100^{\circ} \mathrm{C}$. and after one year of freezing at $20{ }^{\circ} \mathrm{C}$. However, Slanina, et al. (1989) and Rose, et al. (1998) observed ivermectin losses of up to $50 \%$ when bovine muscle was minced before boiling or frying.

The present work aimed to study the incidence of ivermectin residues in cattle meat in some areas at Kafer Elshekh governorate and to determine the stability of this residues against the different methods of conventional cooking (grilling, boiling and frying) ·

\section{MATERIALS AND METHODS}

\section{1- Collection of samples:}

A total of 40 random meat samples were collected from slaughtered cattle at Kafer-Elshekh governorate. They were 12 samples from cattle less than 3 years old (5 native and 7 foreign breed) and 28 samples from cattle more than 3 years old (12 native and 16 foreign breed).Each sample was kept in a separate sterile plastic bag and transferred to the lab in an insulated ice box for detection of its content of ivermectin. Positive meat samples which contained ivermectin were sliced (mean 180 gram) 
after thawing. Each sample was divided into three parts to be cooked by frying for 5 minute each side, roasting for 40 minute at $190^{\circ} \mathrm{c}$ and Boiling for 50 minute. Cooked samples were reweighed after cooking, minced then transferred to the laboratory for analysis.

\section{2- Determination of ivermectin residues:}

For simple and easy sample preparation of ivermectin in bovine tissues, the liquid-liquid extraction (LLE) was adopted based on preliminary report In this study, the samples are extracted with isooctane, followed by delipidation using $\mathrm{n}$-hexane. Then, $5 \mathrm{~g}$ of bovine sample were added to $30 \mathrm{~mL}$ of acetone/ $0.5 \%$ aquatic ammonia (50:50, v/v) and $5 \mathrm{~g}$ of $\mathrm{NaCl}$ in $100 \mathrm{~mL}$ glass tube. This mixture was homogenized for 2 min again (homogenizer)and then this sample was added to $60 \mathrm{~mL}$ of isooctane. This sample solution was vortex-mixed for $5 \mathrm{~min}$, and then centrifuged at $2500 \mathrm{rpm}$ for $5 \mathrm{~min}$. The organic layer was selected to other glass tube. This procedure was performed two times. This isooctane solution was evaporated to dryness at $30^{\circ} \mathrm{C}$. Next step, this residual sample was added to $20 \mathrm{~mL}$ of hexane, and $20 \mathrm{~mL}$ acetonitrile saturated with hexane. This solution was mixed using separating funnel for $5 \mathrm{~min}$. After storing the solution for separation, the lower solution (acetonitrile) was transferred to another tube and evaporated to dryness at $30{ }^{\circ} \mathrm{C}$. The sample was redissolved in $5 \mathrm{~mL}$ of methanol. Analyses were performed using a HPLC instrument (Inoue et al., 2009).

\section{Statistical analysis:}

The data were statistically analyzed according to (SAS, 1987). 


\section{RESULTS}

The results of this study as presented in table (1) and figure (2) revealed that only three $(7.5 \%)$ out of 40 meat samples obtained from slaughtered cattle were contained ivermectin. The mean value of ivermectin residues was $0.011 \mathrm{mg} / \mathrm{kg}$. Also, it was observed as seen in tables ( $2 \& 3$ ) and figure (3)that grilling, boiling and frying of the positive samples induced loses of $25.4 \%, 30.9 \%$ and $23.6 \%$ of ivermectin residues respectively.

Fig. (1): Ivermectin standard curve.

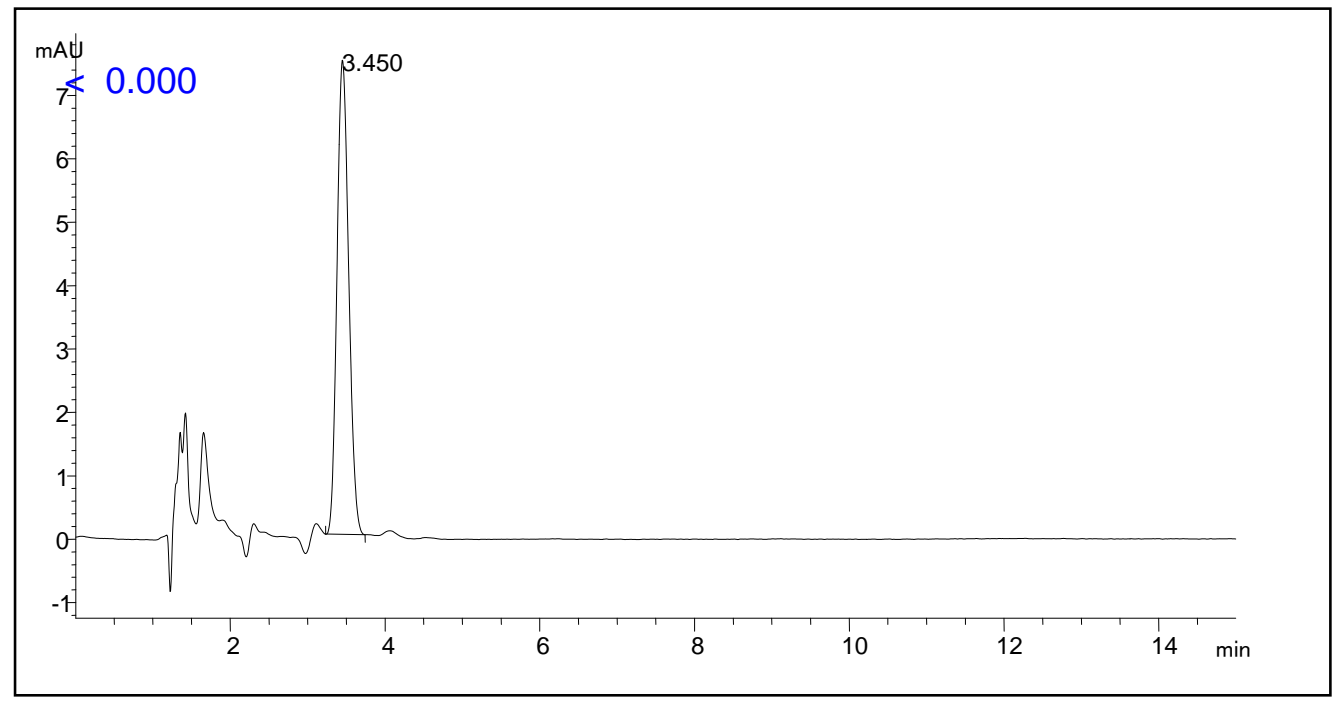

Table (1): Incidance of ivermectin residues in cattle meat

\begin{tabular}{|c||c|c||c|c||}
\hline \multirow{2}{*}{$\begin{array}{c}\text { Number of } \\
\text { samples }\end{array}$} & \multicolumn{2}{|c||}{ Native breed } & \multicolumn{2}{c|}{ Foreign breed } \\
\cline { 2 - 5 } & Less than 3year & More than 3year & Less than 3year & More than 3year \\
\hline \hline Positive samples & 0.0 & 1 & 0.0 & 2 \\
\hline Negative samples & 5 & 11 & 7 & 14 \\
\hline \hline Total & $\mathbf{5}$ & $\mathbf{1 2}$ & $\mathbf{7}$ & $\mathbf{1 6}$ \\
\hline
\end{tabular}

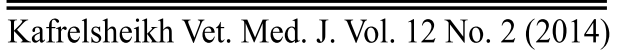


Fig. (2): Percentage of ivermectin residues in cattle meat.

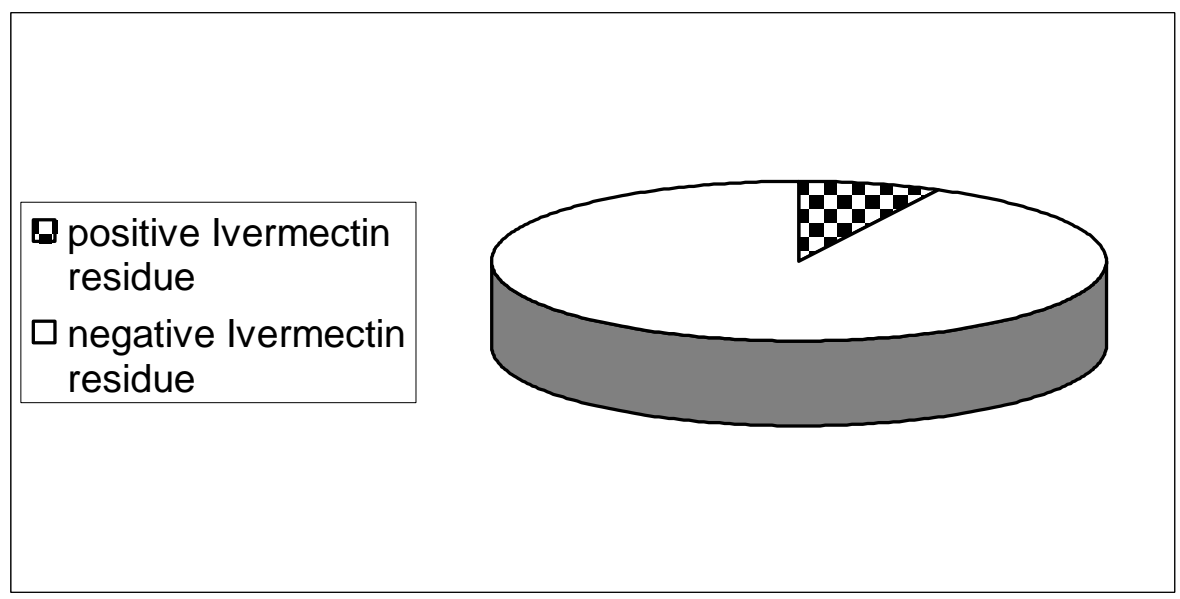

Table (2): The mean values of ivermectin residues $(\mu \mathrm{g} / \mathrm{g})$ in cooked and uncooked cattle meat samples.

\begin{tabular}{|c|c|c|c|}
\hline \multirow{2}{*}{ Uncooked meat } & \multicolumn{3}{|c|}{ Cooked meat } \\
\hline & Frying & Boiling & Grilling \\
\hline $0.00230 .011 \pm$ & $0.0020 .0084 \pm$ & $0.00190 .0076 \pm$ & $00170.0082 \pm$ \\
\hline
\end{tabular}

Fig. (3): Ivermectin residues $(\mu \mathrm{g} / \mathrm{g})$ in cooked and uncooked cattel meat samples.

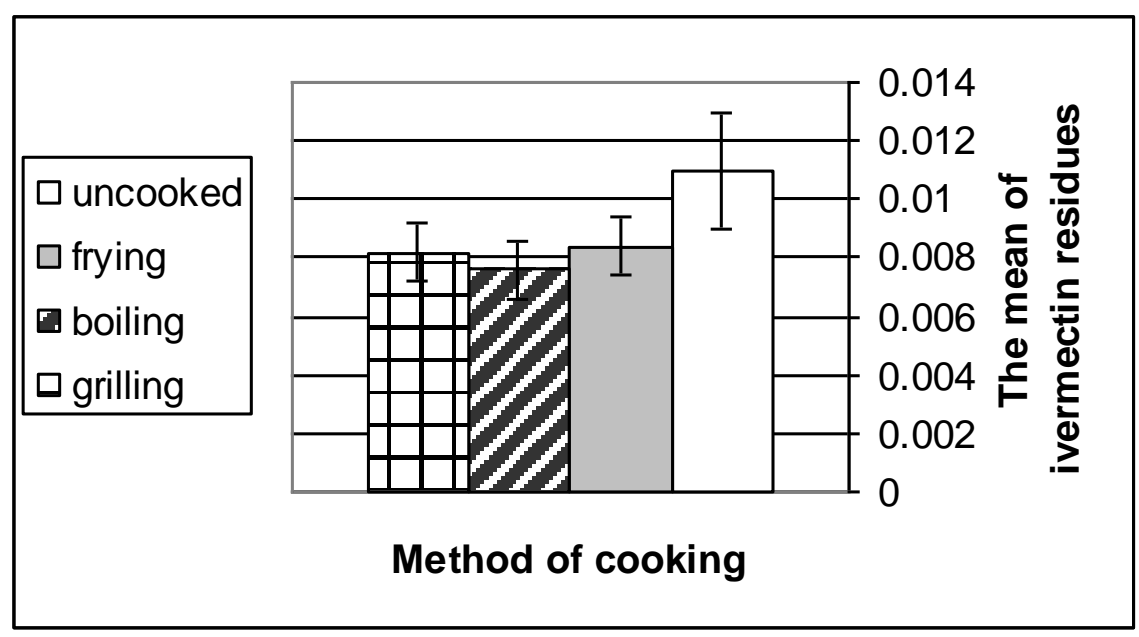

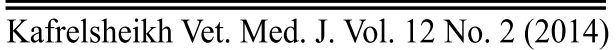


A Study On Ivermectin Residues In The Cattle Meat In ...

Table (3): Effect of cooking on the \% loses of ivermectin residues $(n=3)$.

\begin{tabular}{|c||c||}
\hline Type of cooking & \% Ivermectin loses \\
\hline \hline Frying & $23.6 \pm 0.66^{\mathrm{a}}$ \\
\hline Boiling & $30.9 \pm 0.61^{\mathrm{b}}$ \\
\hline Grilling & $25.4 \pm 0.52^{\mathrm{a}}$ \\
\hline
\end{tabular}

Means within the same row of different letters are significantly different at $(\mathrm{P}<0.05)$.

\section{DISCUSSION}

The use of anthelmintic veterinary drugs in food producing animals has recently become a very public health issue. These agents are widely used for prevention and treatment of parasitic infestation in farm animals .In Egypt there is no program for monitoring these residues and consequently, there are no available data on these residues in meat of slaughtered cattle.

The results in table (1) revealed that only three (7.5\%) out of 40 meat samples obtained from slaughtered cattle contained ivermectin. The mean value of ivermectin residues was $0.011 \mathrm{mg} / \mathrm{kg}$ (within the permissible limits). These animals may be given the drug and slaughtered before its withdrawal period. According to Baynes, et al. (2000) meat withdrawal time in cattle was 35 days. Moreover, Slanina, et al. (1989) reported that withdrawal time for ivomec in edible tissues of swine and cattle was 21 and 28 days, respectively. They added that the highest residue levels were found at the injection site.

The present study demonstrated that ivermectin losses after cooking of the meat samples (grilled, boiling and fried) were $25.4 \%, 30.9 \%$ and Kafrelsheikh Vet. Med. J. Vol. 12 No. 2 (2014) 
$23.6 \%$,respectively. These results are in harmony with those reported by Cooper, et al. (2011) and Rose, et al. (1998). The authors documented that no major losses were observed for residues of ivermectin after cooking .On the other hand, Slanina et, al. (1989) reported that an ordinary culinary preparation of the minced beef muscle from a bull treated with ivermectin resulted in a $45 \%$ (boiling) or $50 \%$ (frying) decrease in the drug residue. Similar results were also recorded by Rose et, al. (1998). The higher loses of ivermectin level may be due to mincing of the bovine muscle before cooking.

\section{CONCLUSION}

It could be concluded that, the level of ivermectin residues in cattle meat in some areas in Kafer Elshekh governorate is accepted and that conventional cooking couldn't be considered a safeguard against ingestion of residues of ivermectin.

\section{REFERNCE}

- Adam, R., H. (2001): Veterinary Pharmacology and therapeutics. 8th edition .philadilpha : WB Sander company.

- Bassissi, M. F; Alvinerie, M and Lespine A. (2004): Comparative Biochemistry Physiology Part C: Toxicol Pharmacol., 2004, 138, 437.

- Baynes, R. E.; Payne, T. M.;Martin-Jimenez, A. R.; Abdullah, K. L.; Anderson, A. I. Webb, A. C. and. Riviere, J. E. (2000): Extralabel use of Ivermectin and moxidectin in food animals. J. Am. Vet. Med. Assoc. 217:668-671. 
- Chiu, S. H. L.; Green, M. L; Baylis, F. P; Eline, D. ;Rosegay, A. Meriwether, H. and Jacob. T. A. (1990). Absorption, tissue distribution, and excretion of tritium-labeled ivermectin in cattle, sheep, and rat. J. Agric. Food Chem. 38:2072-2078.

- Cerkvenik V, Doganoc DZ, Skubic V, Beek WMJ and Keukens, H·J. (2001): Thermal and long-term freezing stability of ivermectin residues in sheep milk. Eur Food Res Technol. 213: 72-76.

- Cooper, K.M; Whelanb, M; Danaherb M. and Kennedyc, D. G. (2011): Stability during cooking of anthelmintic veterinary drug residues in beef. Food Additives and Contaminants 28, 2 (2011) 155.

- FDA. (2011): Tolerances for Residues of New Animal Drugs in Food.Code of Federal Regulations, Sec. 556.334 Ivermectin, Title 21,US Food and Drug Administration, Revised April 1, 2011.

- James, E. and Reynolds, F. (1993). MARTINDALE The Extra Pharmacopeia. 30ed. p. 43-44. Info Access and Distribution Pte Ltd. Singapore.

- Inoue..K; Yoshimi, Y; Hino, T. and Oka, H (2009): Simultaneous determination of avermectins in bovine tissues. J. Sep. Sci. 2009, 32, 3596-3602.

- Koesukwiwat U. Jayanta S. and Leepipatpiboon N. (2007): J. Chromatogr A( 2007), 1140, 147-156. 
- Moreno, L.; Alvarez, L.; Ceballos, L. (2008): Pattern of ivermectin (sheep) and doramectin (cattle) residues in muscular tissue from various anatomical locations. Food additives \& contaminants : part A chemistry, analysis, control, exposure \& risk assessment A. 2008, vol. $25, \mathrm{n}^{\circ} 4$, pp. 406-412.

- Robert, D. and Arthur, C. (1990): Safety, Efficacy, and Tissues residues of ivermectin in reindeer .Rangifer, 2 (10), 1990.

- Rose MD, Farrington WHH and Shearer G. (1998): The effect of cooking on veterinary drug residues in food: 7. ivermectin. Food Addit Contam. 15: 157-161.

- $\boldsymbol{S A S}$ (1987): Statistical analysis system. User' s Guide statistics. SAS Institute Cary, North Carolina.

- Slanina P.Kuivinen J.Ohlsen C.and Ekström L-G.(1989):Ivermectin residues in the edible tissues of swine and cattle: effect of cooking and toxicological evaluation. Food Addit Contam. 6: 475-48.

- Sweetman, S. C. (2009): Martindale. The Complete Drug Reference. Thirty-sixth edition. P. S Blake.

- Veterinary Drugs Directorate. (2011). Topics-Maximum Residue Limits (MRLS). Administrative Maximum Residue Limits (AMRLS), Table of Approved Maximum Residue Limits, and Maximum Residue Limits set by Canada. 
در اسة على متبقيات الافرمكتين فى لحوم الأبقار في بعض المناطق بمحافظه كفر الثيخ

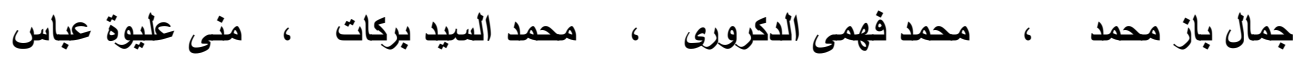

استهدف هذا البحث دراسة متبقيات عقار الايفركنتين في لحوم الأبقار. تم تجميع عدد 40 عينه من لحوم الأبقار عشوائيا من محلات الجزارة بمحافظه كفر الثيخ. تم تجهز العينات وحفظها في التلج ثم أرسلت الى المعمل و ذلك لقياس متنقيات العقار باستخدام جهاز كروماتوجرافيا الأداء العالي (hplc) معظم العينات وجدت سلبيه للفحص (37 عينه) بينما العينات الايجابية كانت 3 عينات فقط وفى الحدود المسموح بها. العينات الايجابية جرى إعادة فحصها بعد إجراء طرق طهى مختلفة وقد اتضح من الدراسة أن عمليات الطهي التقليدية (سلق وشوي وقلى) لم تؤثز على متبقيات العقار بدرجه

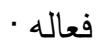

